\title{
Manila clam Tapes philippinarum culture: Sediment-clam interactions
}

\author{
Philippe Goulletquer ${ }^{\left({ }^{*} *\right)}$, René Robert ${ }^{(b)}$, Gilles Trut ${ }^{(c)}$ \\ (a) Laboratoire conchylicole de Poitou-Charentes, Ifremer, B.P. 133, 17390 La-Tremblade, France. \\ (b) Laboratoire de physiologie des invertébrés marins, Ifremer, B.P. 70, 29280 Plouzané, France. \\ (c) Iaboratoire environnement litioral, Ifremer, quai du Commandant-Sithouette, 31200 Arcachon, France.
}

Received December 9, 1997; accepted December 28, 1998.

\begin{abstract}
Manila clam (Tapes philippinarum) culture and sediment interactions were tested by comparing two rearing areas, including an oceanic ('Le-Ferret') and a more estuarine ('Les-Jacquets') sites in the bay of Arcachon (France). The growth of a calibrated clam population $(10-\mathrm{mm}$ spat) was monitored in these two areas with a concomitant sediment-water interface survey over a 1.5-year period. Two sites per area, including control and rearing plots, were sampled on a monthly basis. The potential clam farming impacts by bioturbation and interactions were examined at three sediment depths: $0-1,1-2$ and $2-10 \mathrm{~cm}$. Moreover, the main hydrobiological parameter's were measured on a weekly basis to establish a relationship between these parameters and sediment-water interface characteristics. The existence of a gradient between the three depths was revealed for most of the parameters examined, with the exception of silt and organic carbon levels, and this regardless of the areat examined. Clam growth showed a rate improvement in the oceanic area, which is characterized by a lower silt content. The clam effect was minimal and the activity identified at the 'Ferret' site was in fact due to the presence of a net which acted as a particle trap. No significant relationship was established between water column parameters and those of the sediment-water interface at the two geographical sites examined. These results demonstrate that clam rearing had only a limited effect on the environmental sediment parameters (i.e. water percentage, and phaeopigments and silt levels) from a spatio-temporal point of view. Therefore, a return to environmental conditions existing before the implementation of clam farming is likely to occur upon cessation of this activity. $\odot$ Ifremer/Elsevier, Paris
\end{abstract}

\section{Clam culture / bioturbation / sediment-water interface / Tapes philippinarum / bay of Arcachon}

Résumé - L'élevage de la palourde japonaise Tapes philippinarum : interactions entre le sédiment et les palourdes. Les interactions entre l'élevage de la palourde japonaise lapes philippinarum et le sédiment ont été testées par une comparaison de deux sites d'élevage, comprenant un secteur océanique (Le-Ferret) et un secteur d'influence estuarienne (Les-Jacquets) dans le bassin d'Arcachon (France). La croissance d'une population de naissain calibré (10 $\mathrm{mm}$ de longueur) a été suivie sur ces deux zones avec une étude parallèle de l'interface eau-sédiment pendant une période de 18 mois. Une zone d'élevage et une zone témoin ont été suivies pour chaque site. L'impact potentiel de l'élevage de palourdes a été examiné à trois profondeurs de sédiment : 0-1, 1-2 et $2-10 \mathrm{~cm}$. De plus, les paramètres hydrobiologiques ont été échantillonnés avec une fréquence hebdomadaire afin d'établir une corrélation entre ces derniers paramètres et les caractéristiques de l'interface eau-sédiment. Un gradient de profondeur a été mis en évidence pour la majorité des paramètres hydrobiologiques. à l'exception du contenu en vase fine ( silt ») et des concentrations en carbone organique, et ce, quelle que soit la zone testée. La croissance des palourdes s'est avérée supérieure dans le secteur océanique, caractérisé par un contenu plus faible en vase. L'effet de l'élevage de palourdes sur les caractéristiques sédimentaires fut minime, avec un effet significatif sur le site du Ferret résultant de la présence d'un filet d'élevage agissant comme un piège à particule. Aucune corrélation n'a pu être mise en évidence entre les paramètres de la colonne d'eau et ceux de l'interface eau-sédiment pour les deux zones géographiques testées. Ces résultats démontrent que l'élevage n'a eu qu'un impact limité sur les paramètres sédimentaires (tels que la teneur en eau, en phaeopigments et le pourcentage de vase) d'un point de vue spatio-temporel. Par conséquent, un retour aux conditions environnementales initiales du début de l'élevage est très probable, dès l'arrêt de cette activité. $\odot$ Ifremer/ Elsevier, Paris

Vénériculture / bioturbation / interface eau-sédiment / Tapes philippinarum / bassin d'Arcachon 


\section{INTRODUCTION}

From the middle of the 20th century until today, the French oyster farming industry has had numerous upheavals [20-22]. Severe oyster mortalities led to crises during the early 70 s and eventually to the Portuguese oyster $C$. angulata's disappearance, which prompted managers to massively import the Pacific cupped oyster $C$. gigas [21]. Moreover, since then, the oyster culture's impact on the environment was demonstrated with the siltation process resulting from both oyster biodeposits and rearing structures (i.e. lables), as well as increased organic carbon level, which elevates oxygen demand and, therefore, leads occasionally to anoxic conditions $[8,43]$. Both aspects revealed the critical need to diversify shellfish-farming through the rearing of additional and/or substitute commercially attractive species, including the Manila clam Tapes philippinarum.

In 1974, the know-how of hatcheries and nurseries in terms of spat mass production allowed the first clam rearing facilities to be set up in Brittany [13, 27, 28]. By 1980 , the rearing cycle feasibility was tested at other sites along the Atlantic coast $[2,3,14,17,38$, 48]. The setting-up and the development of this new shellfish industry in France was followed by numerous studies (for a review, see [16]) dealing primarily with the issues of predation $[36,39]$, physiology $[4,9-11$, $15,18,40]$ as well as pathology [33-35]. Since the recent development and spread of natural populations of T. philippinarum along the Atlantic coast, additional studies have been carried out on population dynamics [1] and recruitment processes [10]. Although a large number of studies have examined mollusc-environment relationships (e.g. [19]), few were carried out in vitro $[9,30]$ or considered in situ clam-sediment interactions $[15,24,32,37,45-47,50]$. Although several studies have examined clam farming impact on meiofauna, few considered concomitantly direct physicaltrophic interactions at the sediment level $[7,25]$. This study aims to examine the clam-sediment interactions within the intertidal zone of the Arcachon Bay during a rearing cycle.

\section{MATERIALS AND METHODS}

\subsection{Site distribution}

In order to determine sediment-clams interactions, experimental Manila clam Tapes philippinarum rearings were carried out in two areas of the bay of Arcachon using traditional techniques. The first rearing plot was set up in the 'Jacquets' site which is a relatively protected area where numerous clam farms have been inventoried. In contrast, the second rearing station was set up in a more oceanic area, 'Le-Ferret' (figure l). A calibrated hatchery-produced spat population (mean length $\approx 10 \mathrm{~mm}$ ) was sown at densities of 250 individuals $\cdot \mathrm{m}^{-2}$ on $100-\mathrm{m}^{2}$ rearing plots. The clam

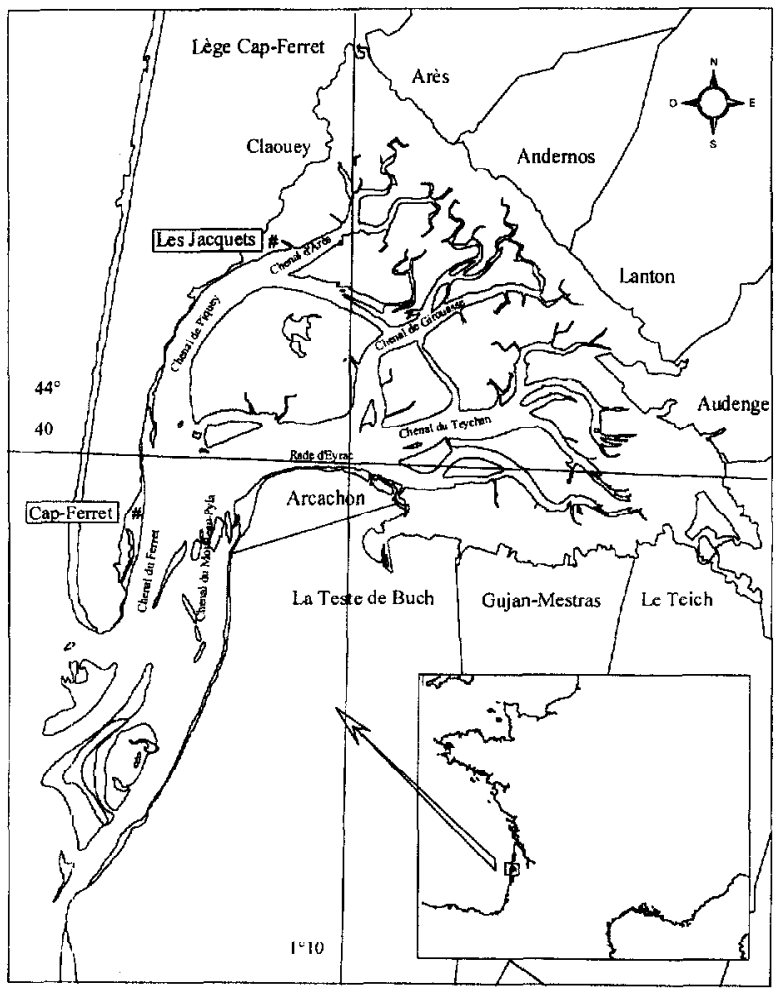

Figure 1. Location of the experimental area (bay of Arcachon) showing clam sampling stations 'Le-Ferret' and 'Les-Jacquets'.

beds were equipped with nets installed temporarily at the 'Jacquets' site (during the summer) and permanently at the 'Ferret' site to limit predation by the common shore crab Carcinus maenas [36], the gray triggerfish Balistes capriscus and the gilthead bream Sparus aurata [39].

\subsection{Clam and sediment monitorings}

Sampling of both clams and sediment was performed from March 1989 to June 1990 on a monthly basis. With regard to clams, shell length and live weight of 30 individuals randomly sampled were measured. For the sediment, seawater and silt (i.e. mineral particles $<63 \mu \mathrm{m}$ ) percentages, chlorophyll $a$, phaeopigments and particulate organic carbon concentrations were determined at the 'Jacquets' and 'Ferret' sites on a monthly and quarterly basis, respectively. At cach site, two areas were sampled: the actual rearing plot and a control plot without clams located in the near vicinity of the former area. In each area, three sediment depths were considered from a core sample: the fraction between 0 and $1 \mathrm{~cm}$, termed the ' 0 ' fraction; the fraction between 1 and $2 \mathrm{~cm}$ referred to as fraction ' 1 '; and finally, the 2 to $10 \mathrm{~cm}$ fraction referred to as fraction '10'. Pre-calibrated $60-\mathrm{mL}$ syringes were used to obtain sediment cores. Ten random cores were obtained for each area. The sediment 
layers obtained in this way were then homogenized in situ using a battery-operated mixer (Black and Decker, model H 223) and divided up into glass vials. All samples were maintained in the dark in an icebox. On return to the laboratory, samples were either immediately analyzed or stored. Water percentage was calculated by double weighing on a precision balance (Mettler AE 163) both before and after drying at $60^{\circ} \mathrm{C}$ for $48 \mathrm{~h}$. Only the sediment fraction below $300 \mu \mathrm{m}$ in size was used to evaluate the other sediment parameters. The silt percentage was determined by a double weighing of the dry matter (drying at $60^{\circ} \mathrm{C}$ for $48 \mathrm{~h}$ ) before and after sifting at $63 \mu \mathrm{m}$. The chlorophyll $a$ and phaeophytin concentrations werc determined based on the technique described by Lorenzen [29] after pigment extraction with $90 \%$ acetone from sediment samples frozen beforehand. Finally, the particulate organic carbon levels were assessed after filtration of sediment samples on a Whatman GF/C filter, oxidation using a sulfo-chromic mixture and quantitative analysis of the oxidant using ferrous sulfate ammonia [12]. The differences in sediment water and silt percentage in chlorophyll $a$, phaeopigments and organic carbon levels existing among the three depths $(0,1$ and $10 \mathrm{~cm}$ ) and between the two study areas (rearing station and control area) were evaluated using twoway analysis of variance for the totality of the data recorded.

\subsection{Hydrobiology monitoring}

In addition, the main hydrobiological parameters were recorded on a weekly basis to detect any possible correlation between these parameters and their sediment counterparts. Sampling at the water bottom was performed at midday in the vicinity of the experimental clam beds either at high tide during spring tides or at low tide during neap tides. Temperature was measured using a field thermo-salinometer probe (YSI model 33). After seawater pre-filtration on a 300- $\mu \mathrm{m}$ filter, the particulate material was retrieved on a 0.45 $\mu \mathrm{m}$ Whatman GF/C filter. The total and organic seston concentrations were determined by double weighing before and after combustion at $450^{\circ} \mathrm{C}$ in a muffle furnace whereas chlorophyll $a$ and phaeopigment concentrations were measured using the fluorometric method [51].

\section{RESULTS}

\subsection{Tapes philippinarum growth}

Shell length and especially live weight of Tapes philippinarum were higher at the 'Le-Ferret' rearing area than at the 'Les-Jacquets' site (figure 2). At both stations, development was poor during the first two months after sowing. Thereafter, growth rates increased sharply with clam sizes doubling within 3 to 4 months after the initial 2 months. Growth rates varied according to season (lower in autumn and winter)

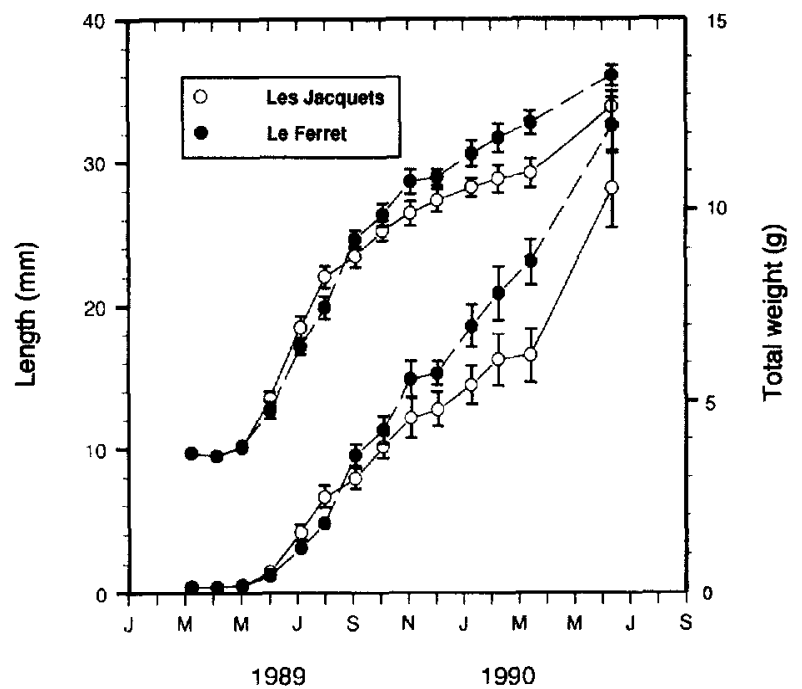

Figure 2. Tapes philippinarum growth in shell length and live weight (means $\pm 95 \%$ confidence intervals) reared in an oceanic station 'LeFerret' and in an inner station 'Les-Jacquets' (bay of Arcachon) from March 1989 to June 1990.

and study area (lower in 'Les-Jacquets'). Nevertheless, the growth rate was satisfactory: during the 16 month culture period, the clams grew from 10 to $34-36 \mathrm{~mm}$ in length (figure 2). Increases in live weight were more constant; at the end of the study, clams weighed between 10 and $12 \mathrm{~g}$ (figure 2).

\subsection{Sediment characteristics}

\subsubsection{Water percentage}

At the 'Jacquets' rearing area, water percentage changes over time revealed the presence of significant differences between both control and clam farming sitcs, and among the three sediment depths examined (figure 3). Within the control area, the water percentage at the 0 and $1 \mathrm{~cm}$ depth varied from 25 to $45 \%$ with slightly higher values at the surface. At the $10 \mathrm{~cm}$ depth, water percentage showed limited variability over time, ranging from 20 to $25 \%$. At this last depth, a similar water percentage trend was observed for all rearing sites whereas the water percentage profiles at the 0 and $1 \mathrm{~cm}$ depth showed large variability over time with values ranging from 30 to $40 \%$ at $1 \mathrm{~cm}$ and the surface, respectively. However, a two-way analysis of variance revealed the highly significant effect of the 'depth' factor and the non-significant 'site' effect on water percentage, although an inversed trend was noted over time between the control and rearing plots (table l). Moreover, a Fisher PLSD multiple comparison test revealed that these differences were highly significant among the three depth levels $(0,1,10 \mathrm{~cm}$, table $I$.

A different profile was observed at the 'Ferret' rearing area. At the control site, values ranged from 15 to $20 \%$ and this regardless of depth. At the rearing site, a 
Table I. Two-way ANOVA: combined effects of depth $(\mathrm{cm})$ and site (with or without clams) on sediment water percentage for both rearing areas (ns, not significant; *, significant; **, very significant; ***, highly significant). Fisher's PLSD multiple comparison tests the depth effect. Depth fraction: '0', 0-1 cm; ' 1 ', 1-2 cm; ' 10 ', 2-10 cm.

\begin{tabular}{|c|c|c|c|c|c|}
\hline Rearing area & Variable & Degree of freedom & Mean square & F-ratio & $P$-value \\
\hline \multirow[t]{9}{*}{ 'Les-Jacquets' } & Main effects & & & & \\
\hline & Depth & 2 & 1273.513 & 55.833 & $0.000 * * *$ \\
\hline & Site & 1 & 0.688 & 0.029 & $0.8647^{\mathrm{ns}}$ \\
\hline & Interaction & 2 & 13.552 & 0.594 & $0.5553^{\mathrm{ns}}$ \\
\hline & Residual & 66 & 22.810 & & \\
\hline & Depth fraction & Mean diff. & Crit. diff. & $P$-value & \\
\hline & $0-1$ & 5.501 & 2.880 & $0.0003^{*}$ & \\
\hline & $0-10$ & 15.037 & 2.880 & $0.0000^{* * *}$ & \\
\hline & $1-10$ & 9.536 & 2.880 & $0.0000^{* * *}$ & \\
\hline \multirow[t]{9}{*}{ 'Le-Ferret' } & Main effects & Degree of freedom & Mean square & F-ratio & $P$-value \\
\hline & Depth & 2 & 116.717 & 5.258 & $0.011^{*}$ \\
\hline & Site & 1 & 292.410 & 1.311 & $0.001^{* * *}$ \\
\hline & Interaction & 2 & 61.609 & 2.776 & $0.0783^{\mathrm{ns}}$ \\
\hline & Residual & 30 & 22.196 & & \\
\hline & Depth fraction & Mean diff. & Crit. diff. & $P$-value & \\
\hline & 01 & 3.532 & 3.928 & $0.0763^{\mathrm{ns}}$ & \\
\hline & $0-10$ & 6.218 & 3.928 & $0.030^{* *}$ & \\
\hline & $1-10$ & 2.687 & 3.928 & $0.1727^{\mathrm{ns}}$ & \\
\hline
\end{tabular}

Table II. Two-way ANOVA: combined effects of depth $(\mathrm{cm})$ and site (with or without clams) on silt percentage for both rearing sediment areas (ns, not significant; *, significant; **, very significant; ***, highly significant). Fisher's PLSD multiple comparison tests the depth effect. Depth fraction: '0', 0-1 cm; '1', 1-2 cm; '10', 2-10 cm.

\begin{tabular}{|c|c|c|c|c|c|}
\hline Rearing area & Variable & Degree of freedom & Mean square & F-ratio & $P$-value \\
\hline \multirow[t]{9}{*}{ 'Les-Jacquets' } & Main effeets & & & & \\
\hline & Depth & 2 & 1151.111 & 18.691 & $0.000^{* * *}$ \\
\hline & Site & 1 & 17.228 & 0.0280 & $0.5986^{\mathrm{ns}}$ \\
\hline & Interaction & 2 & 34.030 & 0.553 & $0.5781^{\text {ns }}$ \\
\hline & Residual & 66 & 61.588 & & \\
\hline & Depth fraction & Mean diff. & Crit diff. & $P$-value & \\
\hline & $0-1$ & 3.379 & 4.523 & $0.1406^{\mathrm{ns}}$ & \\
\hline & $0-10$ & 13.323 & 4.523 & $0.0000^{* * *}$ & \\
\hline & $1-10$ & 9.943 & 4.523 & $0.0000 * * *$ & \\
\hline \multirow[t]{5}{*}{ 'Le-Ferret' } & Main effects & Degree of freedom & Mean square & F-ratio & $P$-value \\
\hline & Depth & 2 & 74.908 & 0.896 & $0.4187^{\mathrm{ns}}$ \\
\hline & Site & 1 & 603.767 & 7.225 & $0.0116^{*}$ \\
\hline & Interaction & 2 & 26.758 & 0.320 & $0.7285^{\mathrm{ns}}$ \\
\hline & Residual & 30 & 83.568 & & \\
\hline
\end{tabular}

similar trend was observed at the 10-cm depth whereas values rose from 15 to $30 \%$ and 20 to $40 \%$ at 1 and $0 \mathrm{~cm}$, respectively (figure 3 ). A two-way analysis of variance revealed the significant effect of study site on water percentage (table I). However, a Fisher PLSD multiple comparison test for the 'depth' effect, revealed that these differences were only significant between the extremes $(0$ and $10 \mathrm{~cm}$, table $)$.

\subsubsection{Silt content}

At the 'Jacquets' rearing area, silt levels ranged from 30 to $60 \%$ at the 0 - and $1-\mathrm{cm}$ depths in the control site with minimum values recorded in September 1989 (figure 3). At $10 \mathrm{~cm}$, lower percentages ranging between 10 and $40 \%$ were observed, although the profile remained the same, as did the September 1989 minimum value. In clam rearing site, a completely different profile was observed with a less distinct differentiation among the three depths and values ranging between 20 and $50 \%$ (figure 3). A two-way analysis of variance revealed the highly significant depth effect and the non-significant effect of study site on silt content (table II). A Fisher's PLSD multiple comparison test, however, showed that these differences were 
(a)
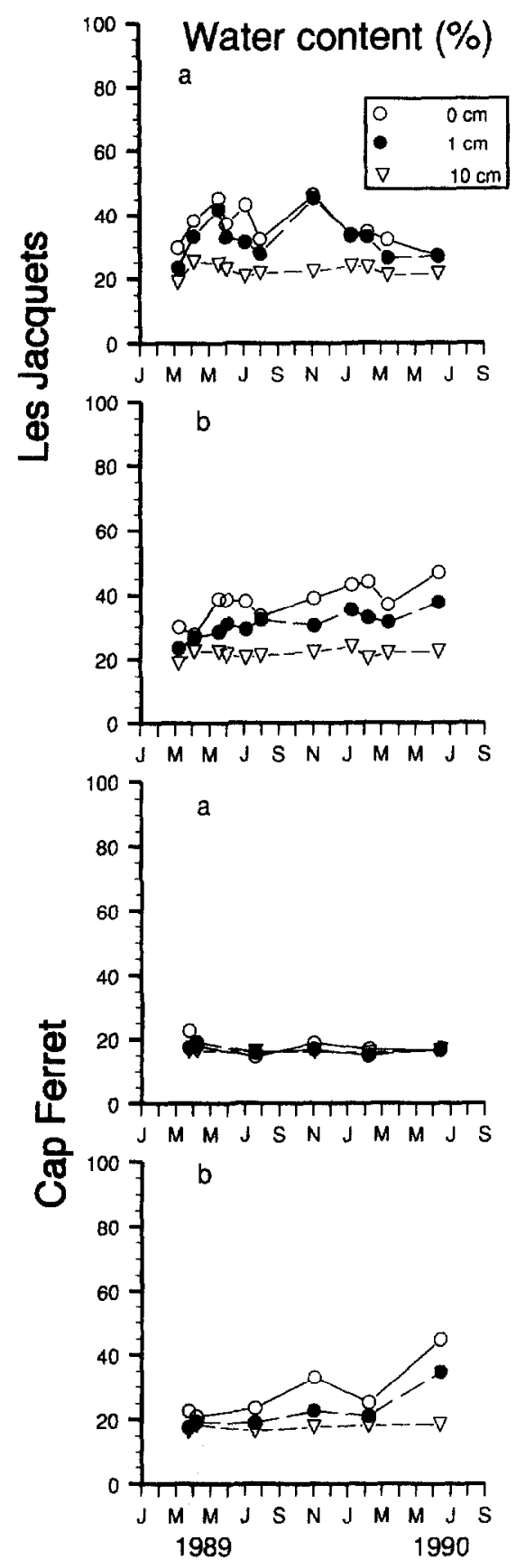

(b)
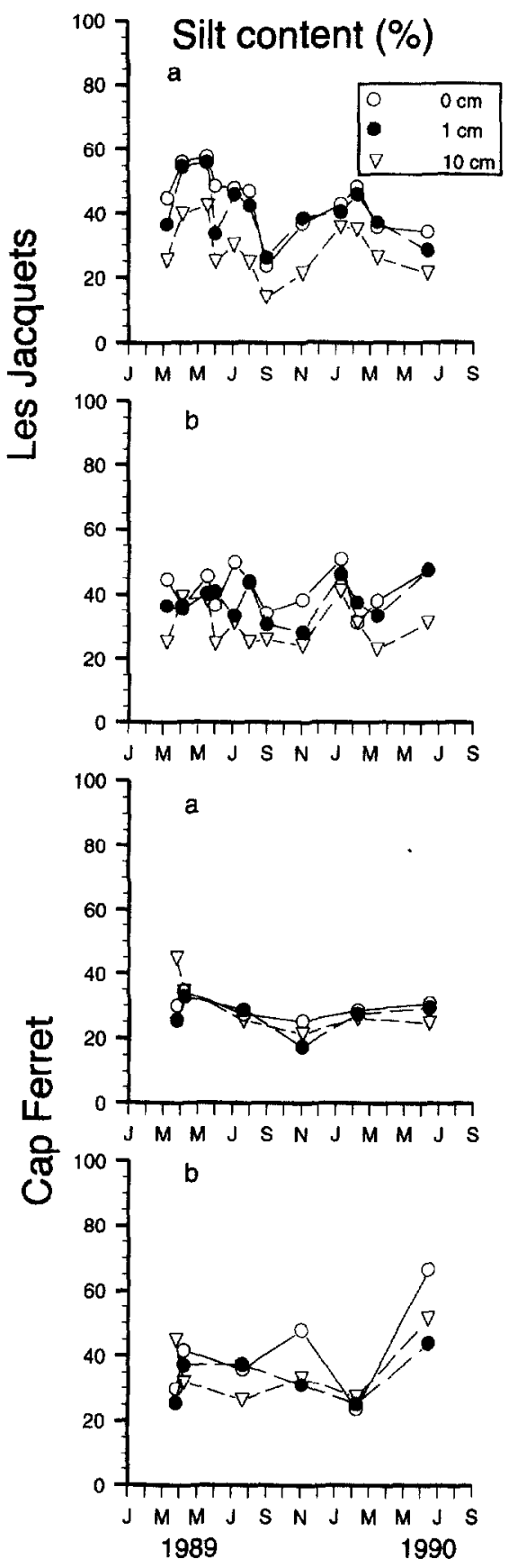

Figure 3. Seasonal variations of sediment water (a) and silt (b) contents at depth layers of $0-1,1-2$ and 2-10 cm in 'Le-Ferret' and 'Les-Jacquets' sites (bay of Arcachon) in control and rearing sites.

all significant but at the 0 - to $1-\mathrm{cm}$ depth fractions (table II).

At the 'Ferret' rearing area, a different silt content evolution was observed. Silt content levels remained low with values ranging from 20 to $40 \%$. In addition, levels remained fairly constant both over time and among the different depths in the control site (figure 3). Based on this last figure, it appears that only the surface layer in the rearing site was noticeably dif- ferent with silt levels between 30 and $60 \%$ (figure 3). A two-way analysis of variance confirmed the nonsignificant depth effect and the significant effect of study site (at $P=0.05$ ) on silt content (table $I I$ ).

\subsubsection{Chlorophyll a and phaeopigment levels}

At the 'Jacquets' rearing area, the chlorophyll $a$ concentration trend in the control site revealed the presence of a gradient among the three recorded depths 
(a)
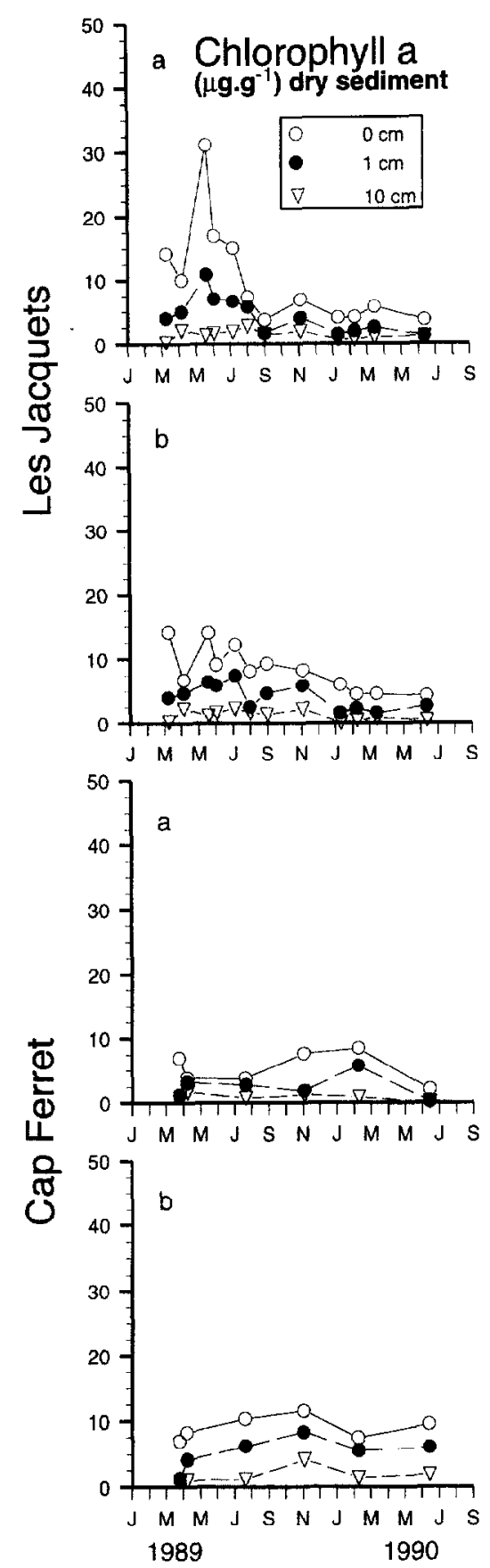

(b)
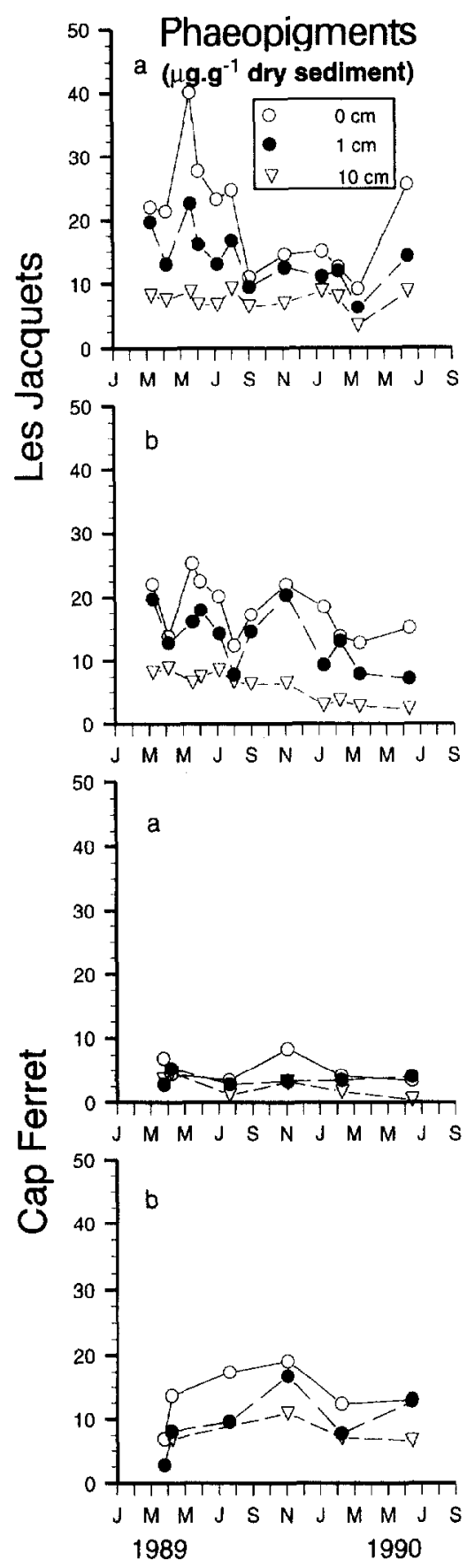

Figure 4. Seasonal variations of sediment chlorophyll $a$ (a) and phaeopigments (b) concentrations at depth layers of $0-1,1-2$ and $2-10 \mathrm{~cm}$ in ' $L e-$ Ferret' and 'Les-Jacquets' sites (bay of Arcachon) in control and rearing sites.

(figure 4$)$. At the surface $(0 \mathrm{~cm})$, concentrations greater than $8 \mu \mathrm{g} \cdot \mathrm{g}^{-1}$ dry sediment were observed from March to August 1989 with a particularly important benthic bloom in May $1989\left(31.18 \mu \mathrm{g} \cdot \mathrm{g}^{-1}\right)$. Earlier values remained well below, ranging from 4 to $8 \mu \mathrm{g} \cdot \mathrm{g}^{-1}$. At 1-cm depth, the chlorophyll a concentrations were approximately the same but with lower levels ranging from 0 to $2 \mu \mathrm{g} \cdot \mathrm{g}^{-1}$. At this last depth, the evolution of chlorophyll $a$ concentrations in the rearing site was similar to that described for the control site, therefore demonstrating the absence of effect due to clam presence (e.g. biodeposits) (figure 4). Moreover, few differences were observed at $1 \mathrm{~cm}$ between these two sites. Conversely, from March to August 1989, surface values $(0 \mathrm{~cm})$ were distinctly lower than those recorded in the control site as they did not exceed $14 \mu \mathrm{g} \cdot \mathrm{g}^{-1}$. A two-way analysis of variance revealed the highly significant depth effect and the non-significant 
Table III. Two-way ANOVA: combined effects of depth $(\mathrm{cm})$ and site (with or without clams) on chlorophyll $a$ concentration for both rearing sediment areas. Fisher's PLSD multiple comparison tests the depth effect. Depth fraction: '0', $0-1 \mathrm{~cm} ;$ ' 1', 1-2 cm; ' 10 ', 2-10 cm.

\begin{tabular}{|c|c|c|c|c|c|}
\hline Rearing area & Variable & Degree of freedom & Mean square & F-ratio & $P$-value \\
\hline \multirow[t]{9}{*}{ Les-Jacquets" } & Main effects & & & & \\
\hline & Depth & 2 & 398.745 & 26.029 & $0.000^{* * * *}$ \\
\hline & Site & 1 & 9.017 & 0.589 & $0.4457^{\mathrm{ns}}$ \\
\hline & Interaction & 2 & 4.873 & 0.318 & $0.7287 \mathrm{~ns}$ \\
\hline & Residual & 66 & 15.319 & & \\
\hline & Depth fraction & Mean diff. & Crit. diff. & $P$-value & \\
\hline & $0-1$ & 5.114 & 2.256 & $0.0000^{* * * *:}$ & \\
\hline & $0-10$ & 8.055 & 2.256 & 0.0000 米: & \\
\hline & $1-10$ & 2.941 & 2.256 & $0.0114^{*}$ & \\
\hline \multirow[t]{9}{*}{ 'Le-Ferret' } & Main effects & Degree of freedom & Mean square & F-ratio & $P$-value \\
\hline & Depth & 2 & 105.819 & 30.160 & $0.000^{* * *}$ \\
\hline & Site & 1 & 49.844 & 14.206 & $0.0007 * * *$ \\
\hline & Interaction & 2 & 5.979 & 1.704 & $0.1991 \mathrm{~ns}$ \\
\hline & Residual & 30 & 3.509 & & \\
\hline & Depth fraction & Mean diff. & Crit. diff. & $P$-value & \\
\hline & $0-1$ & 3.381 & 1.562 & $0.0000 \% * 2$ & \\
\hline & $0-10$ & 5.919 & 1.562 & $0.0000 * * *$ & \\
\hline & $1-10$ & 2.538 & 1.562 & $0.0024^{* * *}$ & \\
\hline
\end{tabular}

effect of study site on chlorophyll a concentrations (table $I I I$ ). Moreover, a Fisher's PLSD multiple comparison test showed that these differences were significant among the three depths examined $(0,1,10 \mathrm{~cm})$ and were highly significant between the depth extremes $(0$ and $10 \mathrm{~cm}$, table $I I)$.

At the 'Ferret' rearing area, a chlorophyll $a$ gradient among the three depths was also revealed. This gradient was morc pronounced in the clam rearing site where levels were generally higher at 0 and $1 \mathrm{~cm}$ with values between 5 and $10 \mu \mathrm{g} \cdot \mathrm{g}^{-1}$ dry sediment (figure 4 ). A two-way analysis of variance revealed the highly significant depth effect and the highly significant effect of study site on chlorophyll $a$ concentrations (table $I I I$ ). Therefore, in contrast to 'Les-Jacquets' area, clam rearing led to a significant increase of chlorophyll $a$ at the sediment level. Moreover, a Fisher's PLSD multiple comparison test showed that these differences were highly significant among the three depths examined $(0$, $1,10 \mathrm{~cm}$, table $I I I)$.

At the 'Jacquets' rearing area, phaeopigments concentrations revealed a gradient among the three depths and this regardless of the study site (figure 4). From March to August 1989, concentrations at the surface $(0 \mathrm{~cm})$ ranged between 20 and $40 \mu \mathrm{g} \cdot \mathrm{g}^{-1}$ for the control site but did not exceed $25 \mu \mathrm{g} \cdot \mathrm{g}^{-1}$ in the rearing site. The opposite trend was subsequently observed as concentrations in the rearing site were seen to be generally higher than those of the control. At $1 \mathrm{~cm}$, phaeopigment levels were approximately the same as those recorded at the surface with lower values ranging from 10 to $20 \mu \mathrm{g} \cdot \mathrm{g}^{-1}$. At $10 \mathrm{~cm}$, phaeopigment lcvels exhibited low seasonal variations with values ranging from 5 to $10 \mu \mathrm{g} \cdot \mathrm{g}^{-1}$ and active chlorophyll levels between 20 and $30 \%$, and this regardless of the study site concerned. The highly significant depth effect at three levels and the non-significant site effect on phaeopigment concentrations are shown in table $I V$.

At the 'Ferret' rearing area, phaeopigment levels in the control site were particularly low being less than $8 \mu \mathrm{g} \cdot \mathrm{g}^{-1}$ and this regardless of depth (figure 4). Conversely, levels were higher in the clam rearing site with a pronounced depth gradient (figure 4). Indeed, values were between 8 and $20 \mu \mathrm{g} \cdot \mathrm{g}^{-1}$ for the 0 - and 1 $\mathrm{cm}$ depths and between 2 and $10 \mu \mathrm{g} \cdot \mathrm{g}^{-1}$ at $10 \mathrm{~cm}$. At this last depth, and for both study sites examined, active chlorophyll rates ranged between 20 and $35 \%$. At the other depths $(0$ and $1 \mathrm{~cm})$, these levels ranged from 30 to $50 \%$. A two-way analysis of variance revealed a significant depth effect (at $P=0.01$ ) and the highly significant site effect on phaeopigment concentrations (table $I V$ ). A Fisher's PLSD multiple comparison test, however, showed that, for depth, these differences were only highly significant between the extremes $(0$ and $10 \mathrm{~cm}$, table $I V)$.

\subsection{Particulate organic carbon}

Particulate organic carbon concentrations in the control and rearing sites of the 'Jacquets' area were observed to evolve heterogeneously with values ranging from 20 to $60 \mu \mathrm{g} \cdot \mathrm{g}^{-1}$ dry sediment (figure 5). This heterogeneity was confirmed by a two-way analysis of variance which revealed for both a non-significant depth $(P>0.36)$ and study site $(P>0.98)$ effect on organic carbon concentrations.

At the 'Ferret' area, these levels exhibited a low seasonal variation with distinctly lower values ranging 
Table IV. Two-way ANOVA: combined effects of depth $(\mathrm{cm})$ and site (with or without clams) on phaeopigment concentration for both rearing sediment areas. Fisher's PLSD multiple comparison tests the depth effect. Depth fraction: '0', 0-1 cm; '1', 1-2 cm: '10', 2-10 cm.

\begin{tabular}{|c|c|c|c|c|c|}
\hline Rearing area & Variable & Degree of treedom & Mean square & F-ratio & $P$-value \\
\hline \multirow[t]{9}{*}{ 'Les-Jacquets' } & Main effects & & & & \\
\hline & Depth & 2 & 954.598 & 39.666 & $0.000 \% * *$ \\
\hline & Site & ] & 41.983 & 1.745 & $0.1911^{\mathrm{ns}}$ \\
\hline & Interaction & 2 & 7.045 & 0.293 & $0.7472^{\mathrm{ns}}$ \\
\hline & Residual & 66 & 24.066 & & \\
\hline & Depth fraction & Mean diff. & Crit. diff. & $P$-value & \\
\hline & $0-1$ & 5.611 & 2.827 & $0.0002^{* * * * *}$ & \\
\hline & $0-10$ & 12.589 & 2.827 & $0.0000 \% * * * *$ & \\
\hline & $1-10$ & 6.978 & 2.827 & $0.0000^{* * * *}$ & \\
\hline \multirow[t]{9}{*}{ 'Le-Ferret' } & Main effects & Degree of freedom & Mean square & F-ratio & $P$-value \\
\hline & Depth & 2 & 77.406 & 8.079 & $0.0016^{* 1 *}$ \\
\hline & Site & 1 & 339.358 & 35.417 & $0.0000^{* * * *}$ \\
\hline & Interaction & 2 & 17.326 & 1.808 & $0.1814^{\mathrm{ns}}$ \\
\hline & Residual & 30 & 9.582 & & \\
\hline & Depth fraction & Mean diff. & Crit diff. & $P$-value & \\
\hline & $0-1$ & 2.805 & 2.581 & $0.0341 \%$ & \\
\hline & $0-10$ & 5.070 & 2.581 & $0.0004 * * *$ & \\
\hline & $1-10$ & 2.265 & 2.581 & $0.0832^{\mathrm{nn}}$ & \\
\hline
\end{tabular}

from 15 to $30 \mu \mathrm{g} \cdot \mathrm{g}^{-1}$ (figure 5), and this regardless of study site and depth. A two-way analysis of variance, however, revealed a non-significant site effect but confirmed a significant study site effect $(P=0.02$ at $P=0.05$ ) on organic carbon concentrations.

\subsection{Hydrobiological parameters trends}

The seston concentrations did not exhibit any discemible cycle with values ranging from 5 to $30 \mathrm{~g} \cdot \mathrm{m}^{-3}$ at the 'Jacquets' and 'Ferret' rearing areas, with only one observation exceeding this range at the latter site $\left(56 \mathrm{~g} \cdot \mathrm{m}^{-3}\right)$ in March 1989 (figure 6a). Evolution of the organic seston was globally quite similar to that of the total seston with values between 1 and $15 \mathrm{~g} \cdot \mathrm{m}^{-3}$ in both areas (figure 6b).

The lack of a spring bloom influenced the chlorophyll $a$ concentration trends in the 'Jacquets' area. In addition, only one fall bloom of low magnitude $\left(7.5 \mathrm{mg} \cdot \mathrm{m}^{-3}\right.$ ) was recorded (September, figure $6 \mathrm{c}$ ). Al this time, chlorophyll $a$ levels in the 'Ferret' area were higher with a maximum of $17.5 \mathrm{mg} \cdot \mathrm{m}^{-3}$ (figure $6 \mathrm{c}$ ). The phaeopigment levels in the water column at both the 'Jacquets' and 'Ferret' areas were of the same order of magnitude as chlorophyll $a$ levels with values ranging from 0 to $10 \mathrm{mg} \cdot \mathrm{m}^{-5}$ (figure $6 \mathrm{~d}$ ). This is contrary to the results obtained at the sediment-water interface.

\section{DISCUSSION AND CONCLUSION}

The impact of oyster farming on trophic capacity and sedimentation has been extensively studied $[5,8$, $23,41,43,44]$, as well as mussel farming impact [49].
However, the effects of clam rearing in the intertidal zone has received very little attention and the available results are often contradictory $[7,25,26,31,45,46]$. By way of example, Castel [7] demonstrated that the disruptive activity of the Manila clam leads to a decrease in the abundance of nematodes but not of copepods. This result can best be explained by an increase in habitat heterogeneity. This author also reveals the existence of a significant effect of clam farming on the biotic and physical characteristics at the sediment-water interface. However, these results seem to depend on the nature of the sediment present [7]. Conversely, Kaiser et al. [25] observed that clam farming had no significant effect on benthic biodiversity other than a non-significant increase in the benthic fauna. They also failed to demonstrate any significant effect on sediment particle size or on organic carbon and chlorophyll pigment contents. A comparison between a control and a rearing site including rearing nets revealed the occurrence of a significant difference in the benthic community as demonstrated by an increase in the number of deposit feeders. This quantitative difference, which has no effect on the biodiversity, is not due to the presence of clams but rather to nets which increase both the sedimentation levels by a factor of 4 and the sediment homogeneity beneath these structures. The clam activity in the absence or presence of nets tends to increase the proportion of silt in the sediment [45-47] (figure 3). Meanwhile, clams may become smothered by sediments that accumulates on nets depending on local sedimentation rates [42]. In the present study, the parameters examined exhibited a greater homogeneity in rearing than in control sites. These differences were further accentuated 

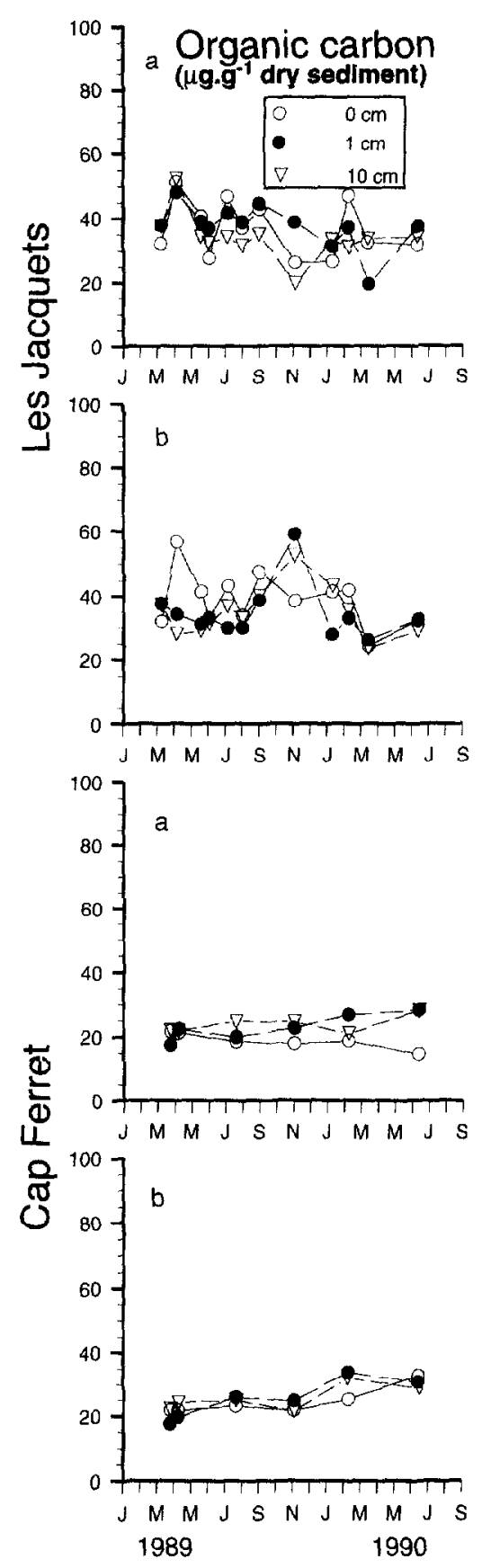

Figure 5. Seasonal varialions of sediment carbon organic concentration at depth layers of $0-1,1-2$ and $2-10 \mathrm{~cm}$ in 'Le-Ferret' and 'LesJacquets' areas in control and rearing sites.

as the clams increased in size. Castel [7] demonstrated that a $20-\mathrm{mm}$ minimal size was necessary to generate significant differences at the sediment-water interface. In the present study, these differences were quite noticeable beginning in the spring of the second year of rearing and corresponded to a resumption of clam growth $(30-\mathrm{mm}$ size). For example, the water percentage in the $0-1-\mathrm{cm}$ depth layer was greater in the con-
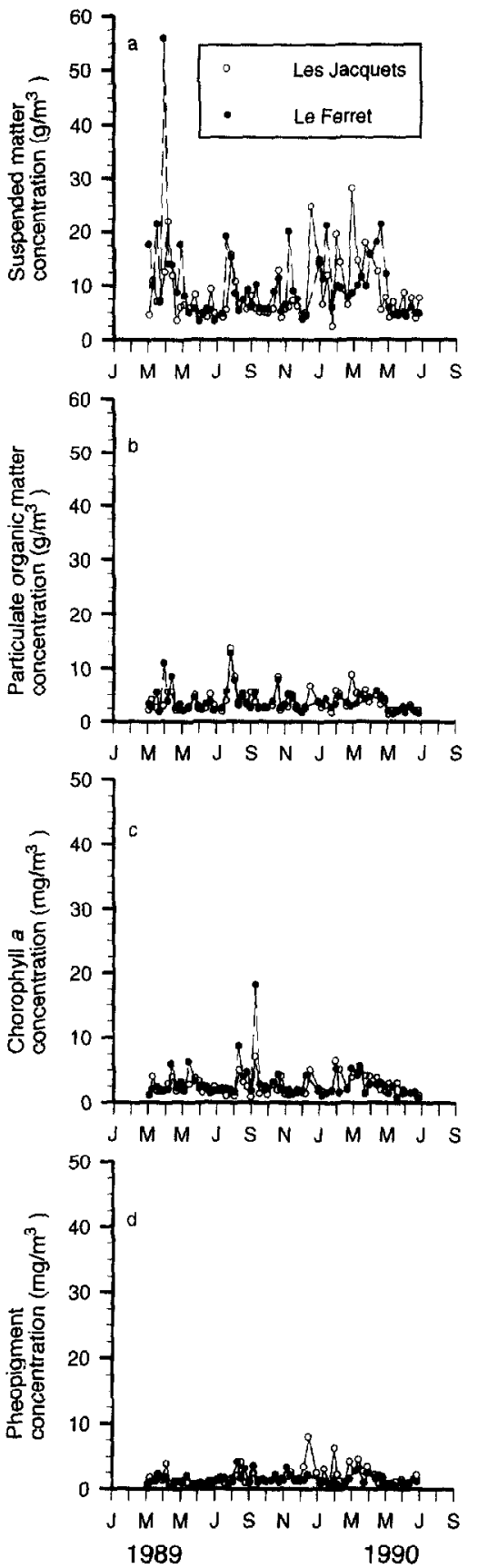

Figure 6. Seasonal variations of suspended matter (a), particulate or ganic matter (b), chlorophyll $a$ (c) and phaeopigment (d) concentrations in seawater in 'Le-Ferret' and 'Les-Jacquets' stations (bay of Arcachon).

trol than in the rearing site (with a more distinct difference observed in the 'Ferret' area), whereas no significant difference was observed at $10 \mathrm{~cm}$ and this regardless of the site examined. The presence of clams only generated a significant increase in silt content in the 'Ferret' area (table II, figure 3). This increase is likely due, in part, to the biological clam activity but is mainly attributable to the mechanical action resulting 
from the permanent presence of rearing nets [42, 45]. The more oceanic geographical location of this last area probably limited this effect as the difference between study sites (with or without clams) was only significant at the $5 \%$ threshold. Conversely, chlorophyll $a$ levels exhibited a distinct gradient among the three depths examined and this in both geographical areas (table III), with the highest values occurring at the surface. At $10 \mathrm{~cm}$, these concentrations were particularly low and did not exceed $2 \mu \mathrm{g} \cdot \mathrm{g}^{-1}$ dry sediment. Once again, the clam presence was only felt in the 'Ferret' area, a difference which can be attributed to a mechanical action, as opposed to a biological activity. An analogous observation was madc for phaeopigments. Indeed, a gradient was observed among the three depths regardless of study site as was a mechanical action due to the presence of permanent nets in the 'Ferret' area. Similar observations have already been reported and the location of rearing areas in habitats where the water is more or less renewed could help explain the observed variability for this parameter $[7,45]$. Conversely, no clearly discernible trend was observed for organic carbon concentrations as the depth effect was not significant in either geographical area examined and as the nets' mechanical action in the 'Ferret' area was only weakly significant $(P<0.05)$.

In both geographical areas examined, it is difficult to establish a relationship between silt levels at the sedi- ment surface and suspended matter concentration trends in the water column (figures 3,6) as the fluctuations of the latter parameter are particularly abrupt. The same is true of organic carbon and particulate organic matter concentrations. As for chlorophyll $a$ and phaeopigment levels, no correlation was established between the phytoplankton blooms of the waler column and those at the sediment surface.

These results demonstrated that clam rearing has only a limited impact on environmental parameters (i.e. water percentage, silt levels, phaeopigments) from a spatio-temporal point of view. Moreover, clam digging associated with the harvesting process was reported as of limited or beneficial impact on the environment [6]. Actually, digging mixes the substrate leading to oxidation of lower sediment parts. Similarly, following suction-harvesting on a muddy sand clam plot, sediment structure and profile were restored after 3 months [47]. It would thus appear that, by taking into consideration hydrodynamic conditions in the selection of aquaculture sites, this impact should be limited even further and, in all cases, will be lower compared to $C$. gigas culture [8]. In light of the limited impact due to bioturbation, it is suggested that a return to environmental conditions existing before the implementation of clam farming will be obtained upon cessation of this rearing activity.

\section{Acknowledgements}

The authors wish to thank J.L. Laborde for his technical field assistance. The experiments reported in the present paper comply with current French laws.

\section{REFERENCES}

[1] Bachelet G., Boucher J., Daguzan J., Glémarec M., Guillou J., Le Pennec M., Mazurié J., Claude S., La prolifération de la palourde japonaise et le déterminisme du recrutement, Programme National sur le Déterminisme du Recrutement, PNDR Information 18, 1993 , pp. 12-23.

[2] Baud J.P., Bacher C., Use of saline ground water for intensive rearing of Ruditapes philippinarum juveniles in a nursery system, Aquaculture 88 (1990) 157-178.

[3] Baud J.P., Haure J., Bodoy A., Intensive culture of the Manila clam Ruditapes philippinarum in marine ponds. The impact of rearing densities and feeding levels on growth rates and yields, Oceanis 18 (1992) 121-132.

[4] Bodoy A., Riva A., Maitre-Allain T., Comparaison de la respiration chez Ruditapes decussatus (L.) et $R$. philippinarum (Adams et Reeve) en fonction de la température, Vie Milieu 36 (1986) 83-89.

[5] Boucher G., Boucher-Rodoni R., In-situ measurement of respiratory metabolism and nitrogen fluxes at the interface of oyster beds, Mar. Ecol. Prog. Ser. 44 (1988) 229-238.

[6] Bourne N., Noakes D.J., Heritage G.D., Effects of repeated digging on sublegal-sized Manila clams Tapes philippinarum, J. Shellfish Res. 17 (1998) 215-221.

[7] Castel J., Influence de l'activité bioperturbatrice de la palourde Ruditapes philippinarum sur les communautés meiobenthiques, C. R. Acad. Sci. Sér. III Sci. Vie 19 (1984) 761-764.

[8] Castel J., Labourg P.J., Escaravage V., Auby I., Garcia M., Influence of seagrass beds and oyster parks on the abundance and biomass patterns of meio- and macrobenthos in tidal flats, Estuar. Coast. Shelf Sci. 28 (1989) 71-85.

[9] Daou R., Goulletquer P., Effets de la turbidité sur les palourdes adultes Ruditapes philippinarum (Adams et Reeve) : croissance, mortalité, effort de reproduction, composition biochimique, Océanis 14 (1988) 375-389.

[10] Defossez J.M., Daguzan J., In-situ orientation of the Manila clam Ruditapes philippinarum: preliminary results, Vie Milieu 46 (1995) 21-25.

Aquat. Living Resour. 12 (1) (1999) 
[11] Defossez J.M., Daguzan J., About preferential ingestion of organic matter by bivalves, J. Moll. Stud. 62 (1996) 394-397.

[12] Etcheber H., Héral M., Relexans J.C., Protocoles d'extraction chimique de la matière organique particulaire : application au domaine estuarien, Océanis 11 (1985) 409-428.

[13] Flassch J.P., Culture de palourdes sur sable en étang marin menée à l'lle Tudy. Résultats et perspectives, Bull. CNEXO 119, 1978, pp. 7-8.

[14] Flassch J.P., L'élevage des palourdes en France en 1987. Aqua Revue 15 (1987) 12-16.

[15] Goulletquer P., Mortalité hivernale chez la palourde japonaise Ruditapes philippinarum sur le littoral atlantique: aspects biochimique et écophysiologique, Haliotis 19 (1989) 215-226.

[16] Goulletquer P., A bibliography of the Manila clam Tapes philippinarum, Ifremer Rapp. DRV-97.02/RA/ La-Tremblade, 1997, 122 p.

[17] Goulletquer P., Nedhif M., Héral M., Perspectives de développement de l'élevage de la palourde japonaise Ruditapes philippinarum dans le bassin ostréicole de Marennes-Oléron, CIEM CM F/42, 1986, pp. 1-14.

[18] Goulletquer P., Lombas I., Prou J., Influence du temps d'immersion sur l'activité reproductrice et sur la croissance de la palourde japonaise Ruditapes philippinarum et l'huître japonaise Crassostrea gigas, Haliotis 16 (1987) 453-462.

[19] Goullelquer P., Héral M., Deslous-Paoli J.M., Prou J., Garnier J., Razet D., Boromthanarat W., Écophysiologie et bilan énergétique de la palourde japonaise d'élevage Ruditapes philippinarum, J. Exp. Mar. Biol. Ecol. 132 (1989) 85-108.

[20] Grizel H., Étude des récentes épizooties de l'huître plate Ostrea edulis Linné et de leur impact sur l'ostréiculture bretonne, thèse dr., Univ. Montpellier, 1985, $145 \mathrm{p}$.

[21] Grizel H., Héral M., Introduction into France of the Japanese oyster (Crassostrea gigas), J. Cons. Int. Explor. Mer 47 (1991) 399-403.

[22] Héral M., L'ostréiculture française traditionnelle, in: Aquaculture, vol. 1, Lavoisier ed., Paris, 1989, pp. 347397.

[23] Héral M., Approche de la capacité trophique des écosystèmes conchylicoles: synthèse bibliographique, ICES Mar. Sci. Symp. 192 (1991) 48-62.

[24] Higano J., Yasunaga Y., Research on sandy and muddy substance for depositing of benthic animals. A consideration about the relation between mud rate of substratum and borrowing behavior of juveniles bivalves, Tech. Rep. Natl Res. Inst. Fish. Eng. 8 (1987) 63-69.

[25] Kaiser M.J., Edwards D.B., Spencer B.E., Infaunal community changes as a result of commercial cultivation and harvesting, Aquat. Living Resour. 9 (1996) $57-63$.

[26] Kaiser M.J., Laing I., Utting S.D., Burnell G.M., Envi ronmental impacts of bivalve mariculture, J. Shellfish Res. 17 (1998) 59-66.

[27] Latrouite D., Claude S., Observations sur le cycle complet d'élevage de palourdes et de clams en surélévation, CIEM CM F/44, 1981, pp. 1-12.

[28] Le Borgne Y., L'écloserie-nurserie de la SATMAR et les possibilités actuelles de production de naissain de

Aquat. Living Resour. 12 (1) (1999) mollusques bivalves, Actes Coll. CNEXO 4, 1977 , pp. 353-360.

[29] Lorenzen C.J., Determination of chlorophyll and pheopigments: spectrophotometric equations, Limnol. Oceanogr. 12 (1967) 343-346.

[30] Mann R., The effect of substrate particle size on growth of the Manila clam Tapes japonica, Tech. Rep. Woods Hole Oceanogr. Inst. MA, 1977, 14 p.

[31] Mojica R., Nelson G., Environmental effects of a hard clam Mercenaria mercenaria aquaculture site in the Indian River lagoon, Florida, Aquaculture 113 (1993) 313-329.

[32] Paillard C., Etiologie et caractérisation de la maladie de l'anneau brun chez la palourde d'élevage Ruditapes philippinarum, thèse dr., Univ. Bretagne-Occidentale, Brest, 1992, 243 p.

[33] Paillard C., Maes P., Étiologie de la maladie de l'anneau brun chez Tapes philippinarum: pathogénécité d'un vibrio sp., C. R. Acad. Sci. 310 (1990) 15-20.

[34] Paillard C., Maes P., The brown ring disease in the Manila clam Ruditapes philippinarum: ultrastructural alterations of the periostracal lamina, J. Invert. Pathol. 65 (1995) 91-100

[35] Paillard C., Percelay L., Le Pennec M., Le Picard D., Origine pathogène de l'« anneau brun" chez Tapes philippinarum (mollusque bivalve), C. R. Acad. Sci. 309 (1989) 235-241.

[36] Parache A., Les relations proie-prédateurs entre le crabe vert Carcinus maenas et la palourde Ruditapes philippinarum, Bull. Mens. Off. Nat. Chasse, N.S., 1980, pp. 299-309.

[37] Plante-Cuny M.R., Bodoy A., Relations trophiques entre microphytes benthiques ou planctoniques et mollusques bivalves endogés, Act. Coll. Ifremer 5 (1987) $157-169$.

[38] Robert R., Deltreil J.P., Élevage de la palourde japonaise Ruditapes philippinarum dans le bassin d'Arcachon. Bilan des dix dernières années et perspectives de développement, Ifremer Rapp. DRV-90.40/RA/ Arcachon, 1990, 21 p.

139] Robert R., Parra R., Étude expérimentale de la prédation de la palourde japonaise Ruditapes philippinarum par la dorade royale, Sparus aurata et le baliste Balistes capriscus, Aquat. Living Resour. 4 (1991) 181-189.

[40] Robert R., Trut G., Laborde J.L., Growth, reproduction and gross hiochemical composition of the Manila clam Ruditapes philippinarum in the Bay of Arcachon, France, Mar. Biol. 116 (1993) 291-299.

[41] Sauriau P.G., Merceron M., Goulletquer P., Aquaculture marine et littorale, in: Dauvin J.C. (Ed.), Les biocénoses marines et littorales françaises des côtes atlantique, Manche, et mer du Nord, synthèses, menaces et perspectives, IEGB/MNHN, Paris, 1997, pp. 195-206.

[42] Smith M.D., Langdon C.J., Manila clam aquaculture on shrimp infested mudflats, J. Shellfish Res. 17 (1998) 223-229.

[43] Sornin J.M., Feuillet M., Héral M., Deslous-Paoli J.M., Effets des biodépôts de l'huître Crassostrea gigas (Thunberg) sur l'accumulation de matières organiques dans les parcs du bassin de Marennes Oléron, J. Moll. Stud. 12A (1983) 185-197.

[44] Sornin J.M., Feuillet M., Héral M., Fardeau J.C., Influence des cultures d'huîtres Crassostrea gigas sur le 
cycle du phosphore en zone intertidale : rôle de la biodéposition, Oceanol. Acta 9 (1986) 313-322.

[45] Spencer B.E., Kaiser M.J., Edwards D.B., The effects of Manila clam cultivation on intertidal benthic community: the early cultivation phase, Aquac. Res. 27 (1996) 261-276.

[46] Spencer B.E., Kaiser M.J., Edwards D.B., The effects of Manila clam cultivation on intertidal benthic community: observations at the end of the cultivation phase, J. Appl. Ecol. 34 (1997) 444-452.

[47] Spencer B.E., Kaiser M.J., Edwards D.B., Intertidal clam harvesting: benthic community change and recovery, Aquac. Res. 29 (1998) 429-437.

[48] St Félix C., Baud J.P., Hommebon P., Diversification de la production conchylicole. Élevage de la palourde japonaise en baie de Bourgneuf, Sci. Pêche 344, 345, 346 (1984) 2-22.

[49] Tenore K.R., Corral J., Gonzales N., Effects of the intense mussel culture on food chain patterns and production in coastal Galicia, North Spain, ICES CM/F 62, 1985, pp. 1-9.

[50] Thompson D.S., Substrate additive studies for the development of hardshell habitat in waters of Puget Sound in Washington State: an analysis of effects on recruitment, growth and survival of the Manila clam Tapes philippinarum and on the species diversity and abundance of existing benthic organisms, Estuaries 18 (1995) 91-107.

[51] Yentsch C.S., Menzel D.W., A method for the determination of phytoplankton chlorophyll and phcophytin by fluorescence, Deep-Sea Res. 10 (1963) 221-231. 